\title{
Under-researched Areas of Event Management in the Past 15 Years
}

\author{
Aguiar-Quintana T* \\ University of Las Palmas de Gran Canaria, Spain
}

\begin{abstract}
This study identifies a gap in the research on quality, satisfaction and loyalty in events in Tourism and Hospitality journals over the last 15 years. Despite the blossoming of tourism studies in recent decades and the resulting development of new areas of enquiry, event tourism studies and related research are still in the early stages of development. Specifically, a total of 4,408 articles were reviewed across five impact journals selected. Our results indicate that, although tourism events generate substantial economic benefits, only $2 \%$ of the articles published have focused on topics related to quality, satisfaction or loyalty on events during the past 15 years. Therefore, event organizers need to better understand perceptions, quality and attendees' loyalty when developing effective strategies to increase attendees' intentions to repeat (revisits) and boost tourism income through the events industry.
\end{abstract}

Considering these research topics according to the different event typologies, our results indicate that the majority of the studies are focused on MICE tourism (58\%), and less on Festivals (31\%), sport events (6.4\%), and public sector events (4.4\%). Therefore, the current study contributes to the literature on Event Tourism by focusing on three aspects or purposes:

1. To identify most of the research in event tourism by the type of event (MICE, Festivals and special events, sport tourism and public sector events), related to the topics of quality, customer satisfaction and loyalty, in the past 15 years;

2. To contribute to the theoretical foundations of the study of events; and

3. To call for research on the topics of quality, satisfaction and loyalty in events tourism. Along with the study findings, implications for practitioners and researchers and suggestions for future research are discussed.

Keywords: Event tourism; Quality; Customer satisfaction; Loyalty; Tourist destination; MICE; Festivals; Sport events; Public sector events

\section{Introduction}

Event Tourism refers to the market for meetings, incentives, conferences and events (MICE), which by extension also includes fairs, exhibitions, festivals, special events besides sports, medical conventions and public sector events.

Tourism Conferences and events undoubtedly play a very important role in the economy of the travel and tourism sector in general, generating substantial income in all the places where they have adequately been developed. Therefore, the main stream of literature has sought to assess economic impacts of specific events, such as conferences and conventions [1], sport events [2] and cultural festivals.

Based on these data, we consider it necessary to discover whether this notorious growth of the Events industry corresponds to an increase in the number of publications on this dynamic sector of the economy, and which topics need more attention in the Events literature. In this line of research, we identify a literature gap, as a large number of studies have been conducted on the economic development and impacts of sponsorship and event marketing from the corporate perspective, whereas less research has been carried out to connect the link between recurring events and subsequent induced repeat attendance [3]. Therefore, there is a lack of studies about the quality perceived by attendees and their satisfaction and loyalty in the different event typologies (Mice, sports, festivals or public administration events).

According to McKerker and Tung [4], prolific authors in tourism, hospitality and events journals tend to concentrate their studies in a small set of well-established journals like the International Journal of Hospitality Management, International Journal of Tourism Research, Tourism Management and Journal of Travel research, among others. By contrast, non-prolific authors are likely to be represented in disciplinespecific journals like the Cornell Hospitality Quarterly, Current Issues in Tourism, Journal of Hospitality and Tourism Management or Journal of Convention and Event Tourism. However, there are other journals with no noted preference that tend to attract a wide array of Tourism topics, such as the Annals of Tourism Research, International Journal of Contemporary Hospitality Management, Journal of Sustainable Tourism or Journal of Vacation Marketing. In an effort to compile the research by Events authors during the past 15 years, we performed a chronological review of two well-established journals (Tourism Management and Journal of Travel Research), two discipline-specific journals (Cornell Hospitality Quarterly and Journal of Convention and Event Tourism), and one generic journal that attracts a wide range of Tourism topics (Journal of Vacation Marketing). Specifically, we found three under-researched areas in Events Management (Quality, satisfaction and loyalty in Events) on the different event typologies.

Better understanding of perceptions, quality and attendees' loyalty is vital to Event Organizers when developing effective strategies to increase attendees' intentions to repeat (revisits) and boost tourism receipts through the events industry. At the same time, extending knowledge about event tourism by examining the research on these

*Corresponding author: Aguiar-Quintana T, University of Las Palmas de Gran Canaria, Las Palmas de Gran Canaria, Spain, Tel: 349284510 00; Email: taguiar@dede.ulpgc.es

Received July 07, 2015; Accepted July 24, 2015; Published July 31, 2015

Citation: Aguiar-Quintana T (2015) Under-researched Areas of Event Management in the Past 15 Years. J Tourism Hospit 4: 160. doi:10.4172/21670269.1000160

Copyright: (c) 2015 Aguiar-Quintana T. This is an open-access article distributed under the terms of the Creative Commons Attribution License, which permits unrestricted use, distribution, and reproduction in any medium, provided the original author and source are credited. 
topics according to the different event typologies remains an important issue to be addressed in the tourism and events literature. Along with the findings of the study, implications for practitioners and researchers and suggestions for future research are discussed.

\section{Chronological Literature Review on Events Tourism}

The events sector was not recognized as an area of separate study within leisure, recreation or tourism during the 1960s and 70s. Boorstin [5] first mentioned the phenomenon of pseudo-events created for political and publicity purposes, and during the 1970s, researchers like Greenwood [6] studied a Basque festival from an anthropological perspective and drew attention to the negative influence of tourism on authentic cultural celebrations. Ritchie and Beliveau [7] studied tourism events through the analysis of the Quebec Winter Carnival and published the first article specifically about event tourism in the Journal of Travel Research. However, we can categorically state that the 1980s was marked by a significant progression of studies on tourist events [8], influenced by events as relevant as the World Fair in Vancouver (1986) and the Calgary Olympic Winter Games (1988), among others. Most of these studies examined the multiple impacts produced by these "mega-events" on the economy, society and culture of the time. This tendency was reflected in the book "The planning and evaluation of hallmark events" [9].

However, in the mid-90s event management studies began to proliferate from the point of view of scientific research, with different studies examining the importance of mega-events in generating tourism demand and measuring the economic impact of events. In the mid90s, a large amount of research materialized, especially in Australia, before the celebration of the Summer Olympic Games in Sydney in the year 2000 [10]. Thus, the end of one millennium and the beginning of another had its impact on the event literature, which increased considerably as the $20^{\text {th }}$ century ended. There was not only a notable increase in the number of studies focused on events, but also a notorious proliferation of subsectors within the events industry, leading to the birth of new disciplinary approaches (meetings, incentive, conference and exhibitions or MICE events, sport events, public administration events, and Festivals and other cultural celebrations). Related to this, in the last decade, Getz [11] concluded that the topics most frequently studied were economic development and impacts, then sponsorship and event marketing from the corporate perspective and general marketing, including motivation and segmentation.

Later, in a literature review by Getz [12], different studies, articles and books of the time are mentioned, and festivals of various kinds (art, anthropology, etc.) are studied. This author pointed out that event tourism studies are still in the early stages of development. The literature review makes it clear that the prevailing theme addresses events as attractions and image-makers for destinations, in addition to some lesser roles (catalyst, place marketing, animator).

However, although competitiveness is a big concern from a tourism and development perspective, there is a gap in the research on topics related to quality, customer satisfaction and loyalty as strategies to increase competitiveness in the events industry. Research has revealed that although quality and responsive service are among the most important criteria in venue selection in the meeting industry [13], very little research has focused on identifying service needs of exhibition attendees in a large convention center, attendees' satisfaction, and loyalty in events. In the past decade, only a few studies, like the one developed by Breiter and Milman [14], have explored attendees' feedback and perceptions to provide the tradeshow industry with some criteria with which to understand the importance of the service elements they provide to attendees and exhibitions. Later, Severt et al. [15] take a new direction in the literature by examining the attendees' perceptions and some of the relationships involved in their decisionmaking processes, including performance evaluation, satisfaction judgement, and behavioral intention regarding the conference. Similarly, Cole and Chancellor [16] examine the festival attributes that impact visitors' experience, satisfaction and revisit intentions, and, Axelsen and Swan [17] design festival experiences to influence visitors' perceptions in wine and food festivals. More recently, residents' perceptions of the impact of a public event are studied by Zhou and Ap [18], whereas Zhang and Ma [19] examine the relationship between exhibition attendees' satisfaction and expenditure on public events.

Finally, in the last decade, we can find some development in the research by event typologies examining attendees' satisfaction, perceptions and loyalty in Mice events [20-23]; sporting events [24]; Festivals [25-27]; special events [28,29]; and public events [30,31]. Nevertheless, there is still a need for more in-depth study of these topics in Event Tourism.

\section{Methodology}

For the theoretical framework, we carried out a review of books and scientific articles on Event Tourism in general. We attempted to locate articles that analyzed at least one of these variables: service quality, customer satisfaction, perceptions and loyalty from the attendees' perspective and from the event planners' perspective in the past 15 years. The search was conducted using these keywords: MICE Tourism, Tourism Event, Festival Events, Sport Events, Medical Convention, Public Sector Event, Quality in Events, Events in Satisfaction, Loyalty in Events, Intent to Return in Events, Revisit Intention in Events and Perceptions in Events (Table 1).

Basically, the methodology analyzes the content of scientific publications selected in the reference period. We consider the McKerker and Tung [4] classification of the preferred journals in Tourism and hospitality, and we carried out the review in well-established journals preferred by prolific authors (Tourism Management and Journal of Travel Research), two other discipline-specific journals preferred by non-prolific authors (Cornell Hospitality Quarterly, originally called Cornell Hotel And Restaurant Administration Quarterly, and Journal of Convention and Event Tourism, originally called Journal of Convention and Exhibition Management). Additionally, we also conducted the review in a journal that attracts a wide array of Tourism topics (Journal of Vacation Marketing). We indicate the main results during this period in Tables 1 and 2 and each author's objectives and findings are illustrated in Appendix 1 (Table 1).

Specifically, a total of 4,408 articles were reviewed across the 5 impact journals selected, as set forth (Table 2). We made the calculation taking into account the 15 years of publications, the number of annual volumes, and the number of articles per volume of each journal. Using this methodology, we were able to quantify the percentage of articles that focus on our research topics in the 5 journals selected. We also established the authors of publications, considering the type of event, the name of the journal, and the year of publication illustrated in Table 3. Then we indicated the origins of the publications and the number of authors per study within each type of event (Table 2).

Furthermore, due to recent interest in the research on attendants' satisfaction, perceived quality and loyalty for events, we also identified different studies related to the quality attributes investigated in these 
Citation: Aguiar-Quintana T (2015) Under-researched Areas of Event Management in the Past 15 Years. J Tourism Hospit 4: 160. doi:10.4172/21670269.1000160

Page 3 of 8

\begin{tabular}{|c|c|c|c|}
\hline Key words & $\begin{array}{l}\text { MICE Tourism } \\
\text { Event Tourism } \\
\text { Festival Events } \\
\text { Sport events } \\
\text { Medical convention } \\
\text { Public sector event } \\
\text { Quality in Events } \\
\text { Satisfaction in Events } \\
\text { Loyalty in Events } \\
\text { Intent to return revisit intention } \\
\text { Perceptions in Events }\end{array}$ & $\begin{array}{l}\text { Journals/years/initials of the } \\
\text { name of the journal }\end{array}$ & $\begin{array}{l}\text {-Tourism Management (2000-2015): TM } \\
\text { - Journal of Convention and Exhibition Management (2000-2004): JCEM } \\
\text { - Journal of Convention and Event Tourism (2005-2014): JCET } \\
\text { - Journal of Travel Research (2000-2015): JTR } \\
\text { - Cornell Hotel And Restaurant Administration Quarterly (2000-2003): } \\
\text { CHRAQ } \\
\text { - CQ Cornell Hospitality Quarterly(2004-May 2014):CQ } \\
\text { - Journal Of Vacation Marketing(2000-2015): JVM }\end{array}$ \\
\hline Period of time analyzed & Years: 2000 to 2015 & & \\
\hline
\end{tabular}

Table 1: Methodology.

\section{Journals}

Tourism Management (2000/January 2015)

Journal of Convention and Exhibition Management (2000/2004)

Journal of Convention and Event Tourism (2005/January 2015)

Journal of Travel Research (2000/January 2015)

Cornell Hotel And Restaurant Administration Quarterly (2000/2003)

CQ Cornell Hospitality Quarterly (2004/January 2015)

Journal Of Vacation Marketing (2000/January 2015)

Total number of articles

\begin{tabular}{|l|} 
Publications \\
2094 articles \\
77 articles \\
195 articles \\
796 articles \\
339 articles \\
482 articles \\
$\mathbf{4 2 5}$ articles \\
$\mathbf{4 4 0 8}$ articles \\
\hline
\end{tabular}

Table 2: Number of Publications in Event Tourism by journal between 2000 and 2015. studies. Therefore, we measure their relative importance based on the number of studies published on each of these issues: Quality in events in a destination; Quality perceived in events in hotels, conference and cruises; Quality of new technologies in events; Quality in food and beverage events; Quality perceived by event planners; Motivations and quality perceived by attendees; Quality management in the event sector; Optimal profile of event planners; and Event quality perceived by locals.

\section{Results}

Following the literature review on event tourism from 2000 to 2015, we performed a more detailed analysis of the results related to our study topics. A total of 4,408 articles were published in the past 15 years in the five journals mentioned, but only 88 studies matched our criteria (Figures 1a and 1b). Therefore, of all the published articles, only $2 \%$ correspond to the topics of our search target in five journals within the area of tourism and with publications about events.

However, during the years 2000, 2008 and 2009, followed by 2001, 2005 and 2011 (coinciding with major events like the end of the century and new millennium, or the FIFA World cup shared by Seoul and Japan in 2005), we found a larger number of studies related to the topics we address. Other important public events like the celebration of the XXIX edition of the modern Olympic Games in Beijing (China) in 2008 or the World Cup in South Africa in 2010 explain the number of sporting events reflected in the majority of publications in 2011 (Figures 1a and 1b).

In addition, the number of studies selected is represented, considering the date and journal of publication, in Table 4 . The results show that more than $50 \%$ of the publications on the topics analyzed were published in the Journal of Convention and Exhibition Management (JCEM, 2000/2004), later called the Journal of Convention and Event Tourism (JCET). Tourism Management published more than 20\% of the articles analyzed, followed by the Journal of Travel Research (12\%). Less research on our study topics was found in the Journal of Vacation Marketing and the Cornell Hotel and Restaurant Administration Quarterly, later called Cornell Hospitality Quarterly, as represented in Figure 2 .

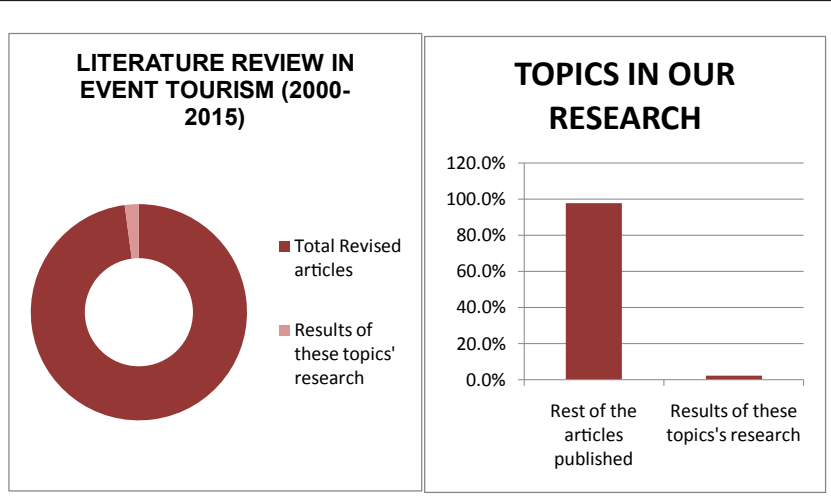

Figure 1: Total Number of articles reviewed and number of publications focusing on our research topics.

\section{EVENT RESEARCH BY YEAR OF PUBLICATION}

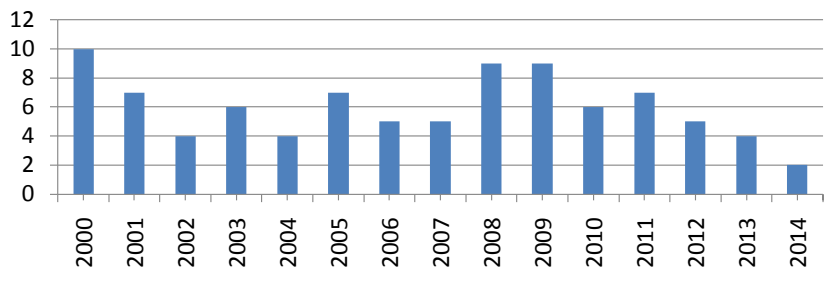

Figure 2: Number of publications on event research by years (2000-2015).

Table 5 presents some of the information needed to develop the conclusions of this review. It shows the salient features of the 88 items selected. Regarding the nationality of the authors of the various studies, the US stands out as the country with the highest number of publications on this topic (54.27\%) followed by China, Australia and 
Citation: Aguiar-Quintana T (2015) Under-researched Areas of Event Management in the Past 15 Years. J Tourism Hospit 4: 160. doi:10.4172/21670269.1000160

Page 4 of 8

\begin{tabular}{|c|c|c|}
\hline \multicolumn{3}{|l|}{ Mice Tourism } \\
\hline Author & Year & Journal \\
\hline Chacko $E$ and Fenich $G$ & $(2000)$ & JVM \\
\hline Nelson $\mathrm{R}$ and Rys $\mathrm{S}$ & $(2000)$ & JCEM \\
\hline Upchurch R, Jeong G, Clements C and Jung I & $(2000)$ & JCEM \\
\hline Kashyap R and Bojanic DC & $(2000)$ & JTR \\
\hline Callan $\mathrm{R}$ and Hoyes $\mathrm{M}$ & $(2000)$ & TM \\
\hline Choi $\mathrm{J}$ and Boger $\mathrm{C}$ & $(2000)$ & JCEM \\
\hline Ngamsom B and Beck J & $(2000)$ & JCEM \\
\hline Campbell $\mathrm{A}$ and Shaw M & $(2000)$ & JCEM \\
\hline Chacko E, Harsha E and Fenich G & $(2000)$ & JVM \\
\hline Weber K and Roehl WS & (2000) & JCEM \\
\hline Fenich G & (2001) & JCEM \\
\hline Ngamsom B, Beck J and Lalopa J & (2001) & JCEM \\
\hline Weber K and Roehl W & (2001) & JCEM \\
\hline Robinson $\mathrm{L}$ and Callan $\mathrm{R}$ & (2001) & JCEM \\
\hline Urdang BS and Howey RM & (2001) & TM \\
\hline Knutson BJ and Kasavana ML & (2002) & JCEM \\
\hline Robinson LS and Callan RJ & (2002) & JCEM \\
\hline Lee TH and Park J & $(2002)$ & JCEM \\
\hline Shoemaker S and Bowen JT & $(2003)$ & CHRAQ \\
\hline Weber $\mathrm{K}$ and Ladkin $\mathrm{A}$ & (2003) & JTR \\
\hline Hinkin TR and Tracey JB & (2003) & CHRAQ \\
\hline Hinkin TR and Tracey JB & (2003) & CHRAQ \\
\hline Baloglu S and Love C & (2003) & JCEM \\
\hline Kim WG and Kim H & $(2004)$ & JCEM \\
\hline Baloglu S and Love C & (2005) & TM \\
\hline Kang M Suh S and Jo D & (2005) & JCET \\
\hline Jung M & (2005) & JCET \\
\hline Robinson LS and Callan RJ & (2005) & JCET \\
\hline Breiter $\mathrm{D}$ and Milman $\mathrm{A}$ & (2006) & TM \\
\hline Akbaba A & $(2006)$ & TM \\
\hline Severt $\mathrm{D}$, Wang $\mathrm{Y}$, Chen $\mathrm{P}$ and Breiter $\mathrm{D}$ & (2007) & TM \\
\hline Ford $\mathrm{R}$ and Peeper W & $(2007)$ & TM \\
\hline Zhang $\mathrm{H}$, Leung $\mathrm{V}$ and $\mathrm{Qu} \mathrm{H}$ & $(2007)$ & TM \\
\hline Pearlman D & (2008) & JCET \\
\hline Boo S, Koh Y, and Jones D & (2008) & JCET \\
\hline De Lara R and Har C & $(2008)$ & JCET \\
\hline McCartney G & $(2008)$ & JCET \\
\hline $\mathrm{Oh} \mathrm{H}$, Kim $\mathrm{H}$ and Hong $\mathrm{K}$ & (2009) & TM \\
\hline Kim Y, Lee $Y$ and Love C & (2009) & JCET \\
\hline Lee $\mathrm{J}$ and Back K & (2009) & JCET \\
\hline Smith SL and Kline SF & $(2010)$ & JCET \\
\hline Kuo $C$, Chen $L$ and Lin $S$ & $(2010)$ & JCET \\
\hline Lee $S$, Close AG and Love $C$ & (2010) & JCET \\
\hline Zeng $\mathrm{X}$ and Yang $\mathrm{J}$ & $(2011)$ & JCET \\
\hline Adongo $\mathrm{R}$ & (2011) & JCET \\
\hline Lee $S$ & (2011) & JCET \\
\hline Tanford S, Montgomery R and Nelson KB & (2012) & JCET \\
\hline Alexander AC, Kim D and Groves J & $(2012)$ & JCET \\
\hline Lin C and Lin CW & (2013) & JCET \\
\hline Wei $Y$ and Huang $Y$ & $(2013)$ & JCET \\
\hline \multicolumn{3}{|l|}{ Sport Events } \\
\hline Authors & Year & Journal \\
\hline Kim S and Chalip L & (2004) & TM \\
\hline Kim S and Morrison A & (2005) & TM \\
\hline Funk $D$ and Bruun $T$ & (2007) & TM \\
\hline Zhou Y and Ap J & (2009) & JTR \\
\hline Shonk DJ, Greenwell TC, Bravo G and Won D & (2012) & JCET \\
\hline Mackellar J and Reis AC & (2014) & JVM \\
\hline Events in the Public Sector & & \\
\hline
\end{tabular}

\begin{tabular}{|l|c|c|}
\hline Authors & Year & Journal \\
\hline Choi J and Boger CA & $(2002)$ & JCEM \\
\hline Choi J & $(2005)$ & JCET \\
\hline Stokes R & $(2008)$ & TM \\
\hline Ayob N, Wahid NA and Omar A & $(2013)$ & JCET \\
\hline Wang C, Yang J, Zhu H and Yu L & $(2014)$ & JCET \\
\hline Festivals snd Special Events & Year & Journal \\
\hline Authors & $(2001)$ & JTR \\
\hline Nicholson RE and Pearce DG & $(2001)$ & JTR \\
\hline Getz D, O'Neill M and Carlsen J & $(2003)$ & JTR \\
\hline Crompton JL & $(2004)$ & TM \\
\hline Gursoy D, Kim K and Uysal M & $(2004)$ & TM \\
\hline Lee C, Lee and Wicks BE & $(2005)$ & JCET \\
\hline Phillips W and Geddie M & $(2006)$ & TM \\
\hline Chang J & $(2006)$ & JCET \\
\hline BBus MA & $(2006)$ & JVM \\
\hline Cole ST and Illum SF & $(2007)$ & JTR \\
\hline Lee S, Petrick J and Crompton J & $(2008)$ & TM \\
\hline Galloway G, Mitchell R, Getz D, Crouch G and & & \\
\hline Ong B & $(2008)$ & JTR \\
\hline Yuan J and Jang S & $(2008)$ & JCET \\
\hline Lee J, Love C and Han T & $(2009)$ & JCET \\
\hline Yolal M, Çetinel F and Uysal M & $(2009)$ & JCET \\
\hline Shani A, Rivera MA and Hara T & $(2009)$ & JVM \\
\hline Cole ST and Chancellor HC & $(2009)$ & JTR \\
\hline Axelsen M and Swan T & $(2009)$ & JVM \\
\hline Mackellar J & $(2010)$ & JVM \\
\hline McDowall S & $(2010)$ & TM \\
\hline Grappi S and Montanari F & $(2010)$ & JCET \\
\hline Zhang L, Qu H and Ma J & $(2011)$ & TM \\
\hline Mason MC and Paggiaro A & $(2011)$ & JCET \\
\hline Kang J and Schrier T & $(2011)$ & JTR \\
\hline Lee J, Lee C and Choi Y & $(2012)$ & JCET \\
\hline Tanford S, Montgomery R and Hertzman J & $(2012)$ & JTR \\
\hline Lee J, Kyle G and Scott D & $(2013)$ & JCET \\
\hline Papadimitriou D & & \\
\hline Tal A A & \\
\hline
\end{tabular}

Table 3: Authors, year of publication and journals that published articles about MICE Tourism.

\section{PUBLICATIONS BY JOURNAL}

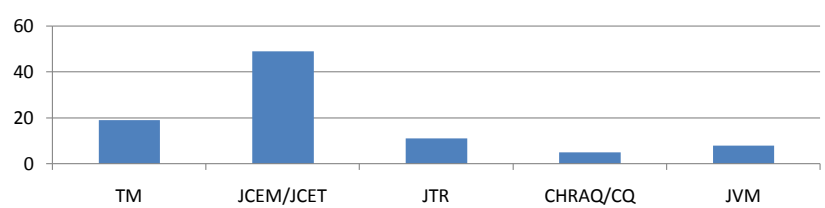

Figure 3: Number of publications selected by journal (2000-2015).

the UK. We also establish the volume of studies by a single author and co-authorship in Table 5. As a result, we observe that studies related to our research topics by two authors predominate. In turn, tourist publications by subject are collected, with MICE tourism representing the largest number of studies on the topics analyzed, followed by studies related to Festivals and Special Events, and on a smaller scale, studies about Sport Events and Public Sector Events. However, no related studies were found about Medical Conventions (Figure 3).

In addition, the number of attributes investigated in each item is reflected in Table 5, which shows that many studies address a single attribute (customer satisfaction, quality or loyalty). Regarding the form 
Citation: Aguiar-Quintana T (2015) Under-researched Areas of Event Management in the Past 15 Years. J Tourism Hospit 4: 160. doi:10.4172/21670269.1000160

Page 5 of 8

\begin{tabular}{|c|c|c|c|c|c|c|c|c|c|c|c|c|c|c|c|c|}
\hline Year of Publication/Journal & 옹 & ్ㅗํ & 옹 & 产 & §ั & No & 옹 & 옹 & 옹 & ํ. & $\underset{0}{\stackrel{N}{0}}$ & $\stackrel{N}{\stackrel{N}{\Xi}}$ & $\stackrel{N}{\stackrel{N}{N}}$ & 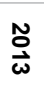 & $\stackrel{N}{\circ}$ & $\begin{array}{c}\text { Total Publications By } \\
\text { Journal }\end{array}$ \\
\hline TM & 1 & 1 & -- & -- & 3 & 2 & 3 & 4 & 2 & 1 & 1 & 1 & -- & -- & -- & 19 \\
\hline JCEM/JCET & 5 & 4 & 4 & 1 & 1 & 5 & 1 & -- & 6 & 3 & 4 & 4 & 4 & 4 & 1 & 47 \\
\hline JTR & 1 & 2 & -- & 2 & -- & -- & -- & 1 & 1 & 2 & 1 & 1 & 1 & -- & -- & 12 \\
\hline CHRAQ/CQ & -- & -- & -- & 3 & -- & -- & -- & -- & -- & -- & -- & & -- & -- & -- & 3 \\
\hline JVM & 2 & -- & -- & -- & -- & -- & 1 & -- & -- & 2 & 1 & -- & -- & -- & 1 & 7 \\
\hline Total Publication Per Year & 9 & 7 & 4 & 6 & 4 & 7 & 5 & 5 & 9 & 8 & 7 & 6 & 5 & 4 & 2 & 88 \\
\hline
\end{tabular}

Table 4: Total publications by journal/year.

\begin{tabular}{|c|c|c|c|c|c|c|c|c|c|c|c|c|c|c|c|c|}
\hline & 1 & 2 & 3 & 4 & 5 & 6 & 7 & 8 & 9 & 10 & 11 & 12 & 13 & 14 & 15 & 16 \\
\hline Year of Publication & 2000 & 2000 & 2000 & 2000 & 2000 & 2000 & 2000 & 2000 & 2000 & 2000 & 2001 & 2001 & 2001 & 2001 & 2001 & 2001 \\
\hline Scientific Journal & JCEM & JCEM & JCEM & JCEM & JVM & TM & JCEM & JCEM & JVM & JTR & JCEM & JCEM & JCEM & JCEM & TM & JTR \\
\hline Authorship country & USA(2) & USA(2) & USA (3) & CAN (2) & USA (2) & USA (2) & USA (2) & $\begin{array}{l}\text { AUS (1) } \\
\text { USA (1) }\end{array}$ & USA (3) & USA (2) & UK (2) & USA (1) & $\begin{array}{l}\operatorname{TAl}(1) \\
\mathrm{USA}(2)\end{array}$ & $\begin{array}{l}\text { AUS (1) } \\
\text { USA (1) }\end{array}$ & USA (2) & $\begin{array}{l}\text { CAN (1) } \\
\text { AUS (2) }\end{array}$ \\
\hline $\begin{array}{l}\text { Individual author/ } \\
\text { Co-authorship (1) }\end{array}$ & C & C & C & C & C & C & C & C & C & C & C & I & C & C & C & C \\
\hline Type of Event (2) & MICE & MICE & MICE & MICE & MICE & MICE & MICE & MICE & MICE & MICE & MICE & MICE & MICE & MICE & MICE & FEE \\
\hline $\begin{array}{l}\text { Num Topics } \\
\text { researched }\end{array}$ & 1 & 1 & 1 & 1 & 1 & 1 & 2 & 1 & 1 & 3 & 1 & 1 & 1 & 2 & 1 & 1 \\
\hline \multirow[t]{2}{*}{ Topics(3) } & Q & $\mathrm{P}$ & $\mathrm{P}$ & $S$ & $\mathrm{P}$ & $\mathrm{P}$ & Q S & $Q$ & $\mathrm{P}$ & QFP & $Q$ & $\mathrm{P}$ & $P$ & QP & $S$ & $Q$ \\
\hline & 17 & 18 & 19 & 20 & 21 & 22 & 23 & 24 & 25 & 26 & 27 & 28 & 29 & 30 & $31 a$ & 31b \\
\hline Year of Publication & 2001 & 2002 & 2002 & 2002 & 2002 & 2003 & 2003 & 2003 & 2003 & 2003 & 2003 & 2004 & 2004 & 2004 & 2004 & 2005 \\
\hline Scientific Journal & JTR & JCEM & JCEM & JCEM & JCEM & JTR & CHRAQ & CHRAQ & CHRAQ & JCEM & JTR & TM & TM & TM & JCEM & JCEM \\
\hline Authorship country & $N Z(2)$ & USA (2) & UK (2) & $\begin{array}{l}\text { KOR (1) } \\
\text { USA (1) }\end{array}$ & $\begin{array}{l}\text { KOR (1) } \\
\text { USA (1) }\end{array}$ & $\begin{array}{l}\text { NZ (1) } \\
\text { UK (1) }\end{array}$ & USA (2) & USA (2) & USA (2) & USA (2) & $\begin{array}{l}\text { USA } \\
\text { (1) }\end{array}$ & USA (2) & USA (3) & $\begin{array}{l}\text { KOR(2) } \\
\text { USA (1) }\end{array}$ & USA (2) & USA (2) \\
\hline $\begin{array}{l}\text { Individual author/ } \\
\text { Co-authorship (1) }\end{array}$ & C & C & C & C & C & C & C & C & C & C & I & C & C & C & C & C \\
\hline Type of Event (2) & FEE & MICE & MICE & FSE & MICE & MICE & MICE & MICE & MICE & MICE & FEE & ED & FEE & FEE & MICE & MICE \\
\hline $\begin{array}{l}\text { Num of topics } \\
\text { researched }\end{array}$ & 1 & 1 & 2 & 1 & 2 & 2 & 2 & 2 & 1 & 2 & 3 & 1 & 1 & 1 & 1 & 1 \\
\hline \multirow[t]{2}{*}{ Topics (3) } & $\mathrm{P}$ & $\mathrm{S}$ & QP & Q & QP & QP & SL & SP & Q & QP & QSP & $\mathrm{P}$ & $\mathrm{P}$ & $\mathrm{S}$ & $\mathrm{P}$ & $\mathrm{P}$ \\
\hline & 32 & 33 & 34 & 35 & 36 & 37 & 38 & 39 & 40 & 41 & 42 & 43 & 44 & 45 & 46 & 47 \\
\hline Year of Publication & 2005 & 2005 & 2005 & 2005 & 2005 & 2005 & 2006 & 2006 & 2006 & 2006 & 2006 & 2007 & 2007 & 2007 & 2007 & 2007 \\
\hline Scientific Journal & TM & TM & JCET & JCET & JCET & JCET & JCET & TM & TM & JCET & JVM & TM & TM & TM & JTR & TM \\
\hline Authorship country & $\begin{array}{l}\text { KOR (1) } \\
\text { USA (1) }\end{array}$ & KOR (3) & USA (3) & AUS (2) & KOR (1) & UK (2) & USA(2) & USA (2) & $\begin{array}{l}\text { TURK } \\
\text { (1) }\end{array}$ & AUS (1) & $\begin{array}{l}\text { USA } \\
(2)\end{array}$ & $\begin{array}{l}\text { AUS } \\
(2)\end{array}$ & $\begin{array}{l}\text { USA } \\
(4)\end{array}$ & USA (4) & $\begin{array}{l}\text { USA } \\
(32)\end{array}$ & USA (2) \\
\hline $\begin{array}{l}\text { Individual authorl } \\
\text { Co-authorship (1) }\end{array}$ & C & C & C & C & C & C & C & C & I & C & C & C & C & C & C & C \\
\hline Type of Event (2) & MICE & SE & MICE & MICE & FSE & MICE & MICE & MICE & FSE & MICE & FSE & SE & MICE & MICE & FSE & MICE \\
\hline $\begin{array}{l}\text { Num of topics } \\
\text { researched }\end{array}$ & 1 & 1 & 1 & 2 & 3 & 2 & 1 & 1 & 1 & 1 & 3 & 1 & 2 & 2 & 3 & 1 \\
\hline \multirow[t]{2}{*}{ Topics (3) } & $\mathrm{P}$ & $\mathrm{P}$ & $\mathrm{P}$ & QS & QSF & QP & Q & $P$ & $\mathrm{P}$ & $\mathrm{P}$ & QSF & $\mathrm{P}$ & SP & $\mathrm{PL}$ & $P Q L$ & $\mathrm{P}$ \\
\hline & 48 & 49 & 50 & 51 & 52 & 53 & 54 & 55 & 56 & 57 & 58 & 59 & 60 & 61 & 62 & 63 \\
\hline Year of Publication & 2008 & 2008 & 2008 & 2008 & 2008 & 2008 & 2008 & 2008 & 2008 & 2009 & 2009 & 2009 & 2009 & 2009 & 2009 & 2009 \\
\hline Scientific Journal & TM & TM & JCET & TM & JCET & JCET & JCET & JCET & JTR & TM & JCET & JCET & JCET & JCET & JVM & JVM \\
\hline Authorship country & $\begin{array}{l}\mathrm{CHI}(2) \\
\mathrm{USA}(1)\end{array}$ & USA (4) & USA (1) & AUS (1) & $\mathrm{CHI}(2)$ & $\mathrm{CHI}(1)$ & $\begin{array}{l}\text { USA(2) } \\
\mathrm{CHI}(1)\end{array}$ & USA(3) & USA (2 & USA (3) & $\begin{array}{l}\text { USA } \\
(3)\end{array}$ & $\begin{array}{l}\text { TURQ (2) } \\
\text { USA (1) }\end{array}$ & $\begin{array}{l}\text { ISR(1) } \\
\text { PR (1) } \\
\text { USA 1) }\end{array}$ & USA (2) & AUS (1) & USA(2) \\
\hline $\begin{array}{l}\text { Individual author/ } \\
\text { Co-authorship (1) }\end{array}$ & C & C & I & I & C & I & C & C & C & C & C & C & C & C & 1 & C \\
\hline Type of Event (2) & MICE & FSE & MICE & PSE & MICE & MICE & MICE & MICE & FSE & MICE & MICE & FSE & FSE & MICE & FSE & FSE \\
\hline $\begin{array}{l}\text { Num of topics } \\
\text { researched }\end{array}$ & 1 & 2 & 1 & 1 & 1 & 1 & 1 & 2 & 3 & 1 & 2 & 2 & 2 & 2 & 3 & 3 \\
\hline \multirow[t]{2}{*}{ Topics (3) } & $\mathrm{P}$ & $P L$ & $\mathrm{P}$ & Q & Q & $\mathrm{P}$ & $\mathrm{P}$ & QS & QS L & $\mathrm{S}$ & S L & $P L$ & $P L$ & PS & QSF & PSL \\
\hline & 64 & 65 & 66 & 67 & 68 & 69 & 70 & 71 & 72 & 73 & 74 & 75 & 76 & 77 & 78 & 79 \\
\hline Year of Publication & 2009 & 2010 & 2010 & 2010 & 2010 & 2010 & 2010 & 2011 & 2011 & 2011 & 2011 & 2011 & 2011 & 2012 & 2012 & 2012 \\
\hline Scientific Journal & JTR & JTR & TM & JCET & JCET & JCET & JCET & JVM & TM & JCET & JCET & JCET & JCET & JTR & JCET & JCET \\
\hline Authorship country & AUS (2) & $\mathrm{CHI}(2)$ & USA (2) & USA(2) & $\begin{array}{l}\mathrm{CHI}(2) \\
\text { USA(1) }\end{array}$ & USA (3) & USA (3) & TAI (2) & ITA (2) & $\mathrm{CHI}(2)$ & UK (1) & USA (2) & $\begin{array}{l}\text { USA } \\
\text { (1) }\end{array}$ & USA (3) & USA (3) & USA(3) \\
\hline $\begin{array}{l}\text { Individual author/ } \\
\text { Co-authorship (1) }\end{array}$ & C & C & C & C & C & C & C & I & C & C & I & C & 1 & C & C & C \\
\hline Type of Event (2) & FSE & SE & MICE & FSE & MICE & MICE & MICE & FSE & FSE & MICE & MICE & MICE & MICE & FSE & FSE & MICE \\
\hline
\end{tabular}




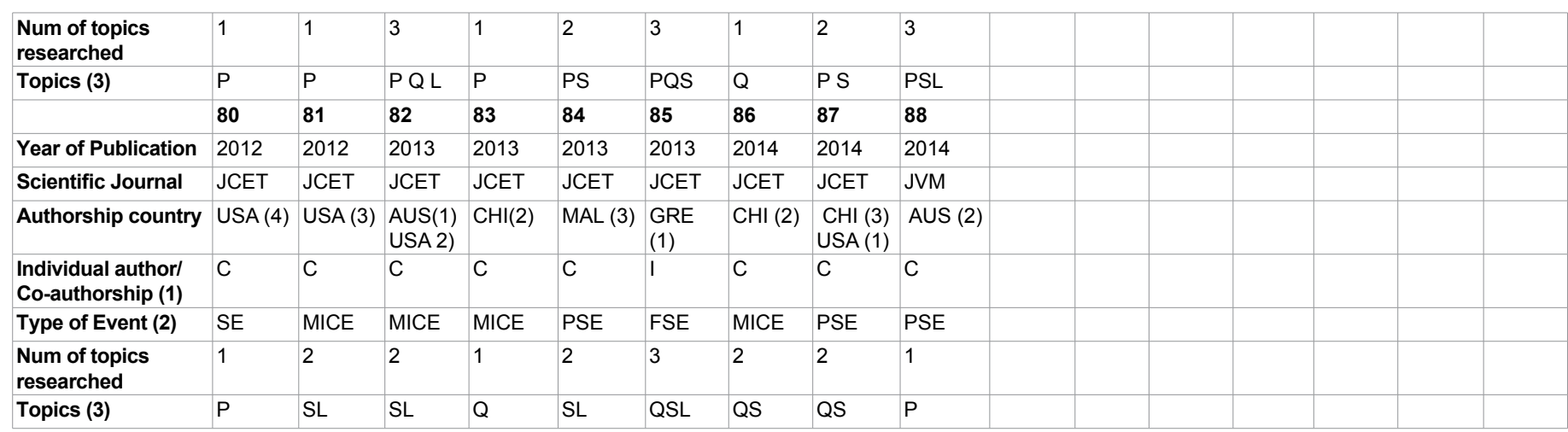

CAN: Canada; UK: United Kingdom; AUS: Australia; TAI: Thailand; NZ: New Zealand; KOR: Korea; CHI: China; TURK: Turkey; MAL: Malaysia; EG: Egypt; ISR: Israel; PR: Puerto Rico; ITA: Italy; GHA: Ghana; GRE: Greece;: 1: I: Individual author; C: Co-authorship: 2: MICE: Meetings Incentives Congresses and Events Tourism; MC: Medical Conventions; SE: Sport Events; PSE: Public Sector Events; FSE: Festivals and Special Events: 3: Q: Quality; S: Satisfaction; L: Loyalty; P: Perception.

Table 5: Number of publications by authorship and attributes.

of participation of the authors in these studies, there are more coauthors (77/88) than authors who publish individually (13/88).

As a result of our research, we find that $30 \%$ of the studies analyzed the motivations and perceived quality of attending such events, with the event organizer profile as the topic addressed the least in the 88 articles of the study (1.1\%). Thus, we measure their relative importance based on the number of studies published on each of these issues: Quality in events in a destination (18.9\%); Quality perceived in events in hotels conference, cruises, etc. (6.7\%); Quality of new technologies in events (3.3\%); Quality in food and beverage events (7.8\%); Quality perceived by event planners (10\%); Motivations and quality perceived by attendees (30\%); Quality management in the event sector $(18.9 \%)$; Optimal profile of event planners (1.1\%); and Event quality perceived by locals (3.3\%) (Table 3). In Table 4 , the number of studies selected is represented considering the publication date and journal.

\section{Discussion}

This study had the goal of reviewing trends in five open-access journals publishing articles in the field of Tourism and Hospitality. The purpose was to analyze the evolution of The Event Tourism research according to its different typologies (MICE Event, Sport Events, Public Sector Events, Medical Conventions and Festivals and Special Events). After finding a gap in the literature, with an abundance of studies focused on the economic impacts of the events, we examine the low number of studies addressing some of the following specific attributes or dimensions: Quality, Satisfaction, Loyalty and/or perceptions in the past fifteen years, in order to quantify the existing research by different types of events. This review provides us with some relevant conclusions:

First, based on the 4.408 articles published in 5 relevant journals on Tourism during the past 15 years, we found only 88 articles that discussed these subjects in the different event typologies (constituting approximately $2 \%$ of the articles reviewed). Specifically, when examining the average number of articles published by journals, the data are quite clear. During this period of time, there was an average of 1.2 articles related to our research topics by year. Nevertheless, some journals only obtain an average of 0.2 articles per year. However, the topics most frequently studied were economic development and impacts, then sponsorship and event marketing from the corporate perspective, and general marketing, including motivation and segmentation.

Secondly, the literature review makes it clear that the prevailing theme is related to events as attractions and image-makers for destinations. However, although from a tourism and development perspective competitiveness is an important concern, there is a gap in the research on topics related to quality, customer satisfaction and loyalty in the different typologies of events during this period of time.

Thirdly, considering only the studies that address our research topics, according to the type of events, MICE tourism has attracted more publications (50/88), representing $57.8 \%$ of the total, followed by literature on Festivals and Special Events (27/88), Sports (6/88) and Public Sector Events (5/88). However, no results were obtained for studies on Medical Congresses.

It is also important to note that $18.9 \%$ of the community of experts focused their research on quality attributes related to convention events organized in specific locations, which gives us an idea of the interest generated by this field. If we add another $18.9 \%$ of studies focused on the management and evaluation of quality in the sector, we find that researchers have also focused their interest on evaluating the quality of the event itself. In this regard, $10 \%$ of the articles dealt with the perceived quality of event organizers, a figure of undeniable importance for the proper development of the sector. These results support the thesis that quality management is especially relevant in events about Meetings, incentives, conferences and exhibitions, where the planners' perceptions and the attendees' perceptions are determinants of service priorities. Since many of the exhibitions in the convention center are annual or rotating events, improved experiences for attendees in the convention center should lead these potential customers to be more likely to return to future events held on the premises. Consequently, this should alert management to direct their priorities to the needs and desires of their customers.

Considering the number of selected variables (quality, satisfaction, loyalty and/or perception), 50 articles focused on a single attribute (56.81\%), while 25 articles considered two research variables (28.4\%). During this period of time, studies examining three variables together were less common (only 14.77\%). Most of the studies consider the attribute of "perception", which appears in 35 of the 88 articles, followed by "quality" which appears in 10 articles. The third attribute studied in events is "satisfaction", with nine articles published on this subject, followed by loyalty or intention to repeat.

By countries, the country that leads the number of publications addressed in this study is the US, unlike other countries, where there is considerable research fragmentation. The research in China and 
South Korea stresses the importance of Event studies, while the UK is in fourth place, despite its long and distinguished career in tourism research. However, in contrast to the case of the United States, in the other three leading countries in congress tourism, no research has been published about our search topics. By country, we also found some differences resulting in major research on the quality of the public sector events developed in China, South Korea and Malaysia, which can be attributed to greater state involvement in the organization of events.

The most important contribution of the present study is that it shows huge differences in the research topics according to the different Event typologies. Our results indicate that, although tourism events are shown to generate enough economic benefits for the destinations where they are held, there is still a gap in the research on the subjects of satisfaction, loyalty and quality perceived by the attendees and event planners. Therefore, there is a need to develop this line of research more in depth. The fact that the current economy is based on an experienced tourist, with an increasing level of demand, has some implications for companies and tourist destinations where events take place, as they must meet these new demands by offering quality services. Primarily, this is the first study to determine that only $30 \%$ of the studies analyzed in the past fifteen years in five tourism and hospitality journals have focused their research on the motivations and quality perceived by the events' attendees, even though these are important topics for the competitiveness of the different types of events.

However, in developing the methodology we included a section for medical congresses because it is a sector with a large number of participants and could be of interest to the scientific community of any country or continent. According to Hosteltur [32], this segment is the one that organizes more events worldwide, about $18 \%$. However, the lack of studies in this field on the topics covered in this study is significant.

One of the limitation of this study, though, is its exclusive focus on specialist journals to the exclusion of tourism-related work published elsewhere (non-tourism journals, conference papers, books, book chapters, and the like).

Regarding the practical implications for tourism conference and events, it is important to note the need to increase the number of studies that measure the attributes of the event tourism product itself, where the conference tourist spends four to six times more than on a normal or holiday trip. Thus, this professional discipline acts as a channel to promote tourist destinations through the attendees, who will return on a future vacation with family or friends. Therefore, it is necessary to invest more in the necessary resources to enhance the perceived quality of congress tourism. If a company and/or destination is perceived as having high quality levels, tourists' satisfaction increases and will have positive effects on their intention to return and their loyalty to the destination and its tourism businesses.

Finally, among the practical implications for companies operating in this sector, we can point out that new technologies are critical to the proper development of the events industry, and so it is essential to incorporate innovations in the Event business sector, thereby giving value to the destination thanks to tourists' positive perceptions. Here big data presents opportunities and challenges, as it may lead to large projects with many authors, further enhancing collaboration opportunities to measure customers' satisfaction, perceptions and loyalty in events held all over the world.

\section{References}

1. Crompton JL, Mackay SL (1997) Motives of visitors attending festival events. Annals of Tourism Research 24: 425-439.

2. Kim HJ, Gursoy D, Lee SB (2006) The impact of the 2002 world cup on South Korea: comparisons of pre- and post -games. Tourism Management 27: 86-96.

3. Lee SK, Jee WSF, Funk DC, Jordan JS (2015) Analysis of attendees expenditure patterns to recurring annual events: Examining the joint effects of repeat attendance and travel distance. Tourism management 46: 177-186.

4. McKercher B, Tung V (2015) Publishing in tourism and hospitality journals: Is the past a prelude to the future? Tourism Management 50: 306-315.

5. Boorstin, D. (1961). The Image. Anthencum, New York

6. Greenwood DJ (1972) Tourism as an agent of change: A Spanish Basque case. Etnology 11: 80-91.

7. Ritchie JRB, Beliveau D (1974) Hallmark events: An evaluation of a strategic response to seasonality in the travel market. Journal of Travel Research 13 : 14- 20.

8. Ritchie JRB (1984) Assessing the impact of hallmark events: conceptual and research issues. Journal of Travel Research 23: 2-11.

9. Syme G, Shaw B, Feston D, Mueller W (eds.) (1989) The planning and evaluation of hallmark events. Aldershot: Gower.

10. Dwyer L, Mellor R, Mistillis N, Mules T (2000) A framework for assessing "tangible" and "intangible" impacts of events and conventions. Event Management 6: 175-189.

11. Getz D (2000) Defining the field of event management. Event Management 6.

12. Getz D (2008) Event tourism: Definition, evolution, and research. Tourism Management 29: 403-428.

13. Baloglu S, Love C (2001) Association Meeting Planners' Perceptions of five major convention cities. Journal of Convention and Exhibition Management 3 : 21-30.

14. Breiter D, Milman A (2006) Attendee's needs and service priorities in a large convention center: Application of the importance - performance theory. Tourism Management 27: 1364-1370.

15. Severt D, Wang Y, Chen P, Breiter D (2007) Examining the motivation, perceived performance and behavioral intentions of convention attendees: evidence from a regional conference. Tourism Management 28: 399-408.

16. Cole ST, Chancellor HC (2009) Examining the festival attributes that impact visitor experience, satisfaction and re -visit intention. Journal of Vacation Marketing 15: 323-333.

17. Axelsen M, Swan T (2009) Designing Festival Experiences to Influence visitor Perceptions: The Case of a Wine and Food Festival. Journal of Trave Research 49: 436-450.

18. Joe ZY, Ap J (2009) Residents' Perceptions towards the Impacts of the Beijing 2008 Olympic Games. Journal of Travel Research 48: 78-91.

19. Zhang L, Qu H, Ma J (2010) Examining the Relationship of Exhibition Attendees' Satisfaction and Expenditure: The Case of Two Major Exhibitions in China Journal of Convention and Event Tourism 11: 100-118.

20. Lee S (2011) To Tweet or Not To Tweet: An Exploratory Study of Meeting Professionals' Attitudes towards Applying Social Media for Meeting Sessions Journal of Convention and Event Tourism 12: 271-289.

21. Tanford S, Montgomery R, Nelson KB (2012) Factors that Influence Attendance, Satisfaction, and Loyalty for Conventions. Journal of Convention \& Event Tourism 13: 290-318.

22. Lin C, Lin CW (2013) Exhibitor Perspectives of Exhibition Service Quality Journal of Convention and Event Tourism 14: 293-308.

23. Wei YP, Huang YC (2013) The Impact of Food Quality on Foodservice Satisfaction at International Conferences. Journal of Convention and Event Tourism 14: 252-269.

24. Shonk DJ, Greenwell TC, Bravo G, Won D (2012) Site Selection, Satisfaction, and Intent to Return: An Exploratory Study of the Perceptions of Rights Holders of Small-Scale Sporting Events. Journal of Convention \& Event Tourism 13 $1-15$. 
Citation: Aguiar-Quintana T (2015) Under-researched Areas of Event Management in the Past 15 Years. J Tourism Hospit 4: 160. doi:10.4172/21670269.1000160

Page 8 of 8

25. Lee J, Lee C Choi $Y$ (2011) Examining the role of emotional and functional values in festival evaluation. Journal of Travel Research 50: 685-696.

26. Lee JJ, Kyle G, Scott D (2012) The mediating effect of place attachment on the relationship between festival satisfaction and loyalty to the festival hosting destination. Journal of Travel Research 51: 754-767.

27. Papadimitriou D (2013) Service Quality Components as Antecedents of Satisfaction and Behavioral Intentions: The Case of a Greek Carnival Festival. Journal of Convention and Event Tourism 14: 42-64.

28. Tanford S, Montgomery R, Heertzman J (2012) Towards a Model of Wine Event Loyalty. Journal of Convention \& Event Tourism 13: 77-99.
29. Ayob N, Wahid NA, Omar A (2013) Mediating Effect of Visitors' Event Experiences in Relation to Event Features and Post-Consumption Behaviors. Journal of Convention and Event Tourism 14: 177-192.

30. Wang C, Yang J, Zhu H, Yu L (2014) Research on Foreign Tourists' Satisfaction with the 2010 Shanghai World Expo: Based on the Blogs at a Travel Website. Journal of Convention and Event Tourism 15: 114-134.

31. Mackellar J, Reis AC (2014) World Rally Championships 2009 and 2011 Assessing the tourism value in Australia. Journal of Vacation Marketing 20 $17-28$.

32. Hosteltur (2013) Informe Anual de Tendencias en Turismo Mice.
Citation: Aguiar-Quintana T (2015) Under-researched Areas of Event Management in the Past 15 Years. J Tourism Hospit 4: 160 doi: $10.4172 / 21670269.1000160$
Submit your next manuscript and get advantages of OMICS Group submissions

Unique features:

User friendly/feasible website-translation of your paper to 50 world's leading languages

Audio Version of published paper

Digital articles to share and explore

Special features:

400 Open Access Journals

30,000 editorial team

21 days rapid review process

Quality and quick editorial, review and publication processing

Indexing at PubMed (partial), Scopus, DOAJ, EBSCO, Index Copernicus and Google Scholar etc

- Sharing Option: Social Networking Enabled

- Authors, Reviewers and Editors rewarded with online Scientific Credits

- Better discount for your subsequent articles

Submit your manuscript at: http://www.omicsonline.org/submission 